Sains Malaysiana 50(6)(2021): 1715-1726

http://doi.org/10.17576/jsm-2021-5006-18

\title{
Immunomodulatory Properties of Wharton's Jelly-Derived Mesenchymal Stem Cells from Three Anatomical Segments of Umbilical Cord
}

(Sifat Imunomodulasi Sel Stem Mesenkima Jeli Wharton yang Dipencilkan daripada Tiga Segmen Anatomi Tali Pusat)

\author{
Jezamine Lim, Sue Ping Eng, Wei Yen Yeoh, Yik Wan Low, Nur Mohd Shafwan bin Jusoh, Ain SyahiRaH \\ BINTI RAHMAT, AMIRAH SHAHRANI, FAIQ BAHRANI YAHYA, RUSHDA AdIBA ABDUl RAHMAN, ZAINUL RASHID \\ Mohamad Razi, Chooi Fun LeOng, SHinsmon Jose \& Min HWeI NG*
}

\section{ABSTRACT}

Mesenchymal stem cells (MSCs) are multipotent progenitor cells that are reported to be immune-privileged and immuneevasive. MSCs are capable of differentiating into specific cell types for subsequent use in cell-based therapy. They express low levels of human leucocyte antigen (HLA)-ABC and no HLA-DR. Wharton's jelly-derived MSCs (WJ-MSCs) were also found to express human leukocyte antigen $G(H L A-G)$, which renders them immunosuppressive. This study aimed to determine whether cultured WJ-MSCs retain their immune-privileged and immune-evasive properties after cell differentiation, and whether these properties differ among MSCs derived from different anatomical segments of the umbilical cord. Umbilical cords of healthy pregnant mothers undergoing caesarean section were obtained and grouped by three anatomical segments: fetal, middle, and maternal segments. WJ-MSCs were isolated, culture-expanded, and differentiated into osteogenic cells. Expression of HLA-DR, HLA-ABC, and HLA-G were quantified using flow cytometry. Both undifferentiated and osteodifferentiated WJ-MSCS were subsequently co-cultured with allogeneic peripheral blood mononuclear cells with/without lipopolysaccharide (LPS) stimulation for five days. Lymphocyte proliferation assay was performed using carboxyfluorescein succinimidyl ester (CFSE) as a tracker. Our results showed no significant difference existed in the HLA profiles among WJ-MSCs from different segments and between WJ-MSCs with and without osteogenic

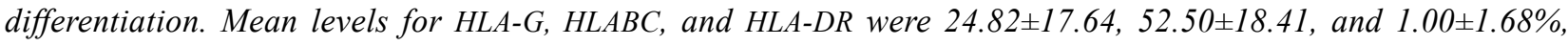
respectively. Stimulation with LPS and WJ-MSCs increased peripheral blooc mononuclear cells (PBMC) proliferation. However, PBMC proliferation was significantly lower when PBMCs were co-cultured with osteodifferentiated WJ-MSCs ( $p$ $<.05$; with LPS stimulation and $p<.001$ without LPS stimulation) than when they were co-cultured with undifferentiated WJ-MSCs. These findings suggest that cultured WJ-MSCs stimulate lymphocyte proliferation and are not immune-privileged. Osteodifferentiated WJ-MSCs reduced the immunogenicity of WJ-MSCs, and this reduction in PBMC proliferation was even more pronounced in the presence of LPS $(p<.05)$. In conclusion, cultured WJ-MSCs are not immune-privileged. Osteodifferentiated WJ-MSCs are less immunogenic than undifferentiated WJ-MSCs, in which case hypoimmunogenicity is more profound under LPS-stimulated conditions.

Keywords: Immunomodulation; peripheral blood mononuclear cells; umbilical cord; Wharton's jelly mesenchymal stem cell

\section{ABSTRAK}

Sel Stem Mesenkima (MSCs) adalah sel progenitor multipoten yang boleh membeza menjadi sel yang khusus dan ini berpotensi digunakan untuk membaikpulih tisu yang rosak. MSC juga mempunyai sifat menindas atau mengelak gerak balas imun kerana ia mengungkap antigen leukosit manusia kelas I iaitu HLA-ABC yang rendah malah tidak mengungkap antigen leukosit manusia kelas II iaitu HLA-DR. Satu keistimewaan sel stem mesenkima yang dipencil daripada bahagian jeli Wharton tali pusat (WJ-MSCS) ialah ia juga menggunakan HLA-G, sejenis antigen leukosit kelas I dan ini menyebabkan WJ-MSC mempunyai daya menindas gerak balas imun yang lebih tinggi. Dalam kajian ini, matlamat kami adalah untuk menentukan sama ada WJ-MSC yang dipencilkan daripada segmen tali pusat yang berlainan dapat 
mengekal keistimewaan keimunan asalnya. Tali pusat daripada ibu yang sihat dan menjalani pembedahan caesarean telah diperoleh dan dibahagikan kepada tiga segmen anatomi, iaitu segmen bahagian fetus, tengah dan ibu. Selepas itu, WJ-MSCs dipencilkan, dikultur dan dibezakan kepada sel osteogenik. Ekspresi HLA-DR, HLA-ABC dan HLA-G diukur melalui sitometri aliran. WJ-MSCs yang dibezakan kepada sel osteogenik atau MSC asli dibiakkan bersama dengan sel mononuklear darah alogenik dengan atau tanpa rangsangan lipopolisakarida (LPS) selama 5 hari. Ujian proliferasi sel limfosit dijalankan menggunakan ester karboksifluoresein sinksinmidil (CFSE) sebagai penanda jejak. Hasil daripada kajian ini menunjukkan bahawa tiada perbezaan yang signifikan dalam profil HLA antara WJ-MSCs daripada segmen yang berbeza dan juga antara WJ-MSC asli dan WJMSC pembezaan osteogenik. Purata ungkapan HLA-G, HL-ABC dan HLA-DR masing-masing adalah 24.82.0 $\pm 17.64,52.50 \pm 18.41,1.00 \pm 1.68 \%$. Penambahan LPS merangsang proliferasi sel limfosit. Tetapi, apabila sel limfosit dikultur bersama dengan WJ-MSC daripada segmen yang berbeza, proliferasi sel limfosit menurun $(p<.05$; dengan rangsangan LPS) dan $(p<.001$ tanpa rangsangan LPS). Penemuan ini mencadangkan bahawa WJ-MSC sebenarnya tidak dapat mengelak gerak balas imun. WJ-MSC pembezaan osteogenik dapat mengurangkan keimunogenan WJ-MSC dan penurunan proliferasi sel limfosit adalah lebih ketara apabila sel limfosit dirangsang oleh LPS ( $p<.05)$. Secara kesimpulan, WJ-MSC tidak dapat mengelak gerak balas imun. WJ-MSC pembezaan osteogenik kurang keimunogenan daripada WJ-MSC asli, lebih-lebih lagi jika dirangsang oleh LPS.

Kata kunci: Keimunogenan; sel limfosit; sel stem mesenkima jeli Wharton; tali pusat

\section{INTRODUCTION}

Mesenchymal stem cells (MSCs) are multipotent cells that can differentiate into cell lineages of mesodermal origin, such as adipocytes, chondrocytes, and osteocytes (Pittenger et al. 1999). MSCs can be found in many tissues, such as bone marrow; adipose; peripheral blood; mucosa layer; and neonatal birth-associated tissues, including placenta, umbilical cord, and cord blood. Perhaps, MSCs are stem cells that have been well studied for their genomic stability and functionality in clinical application, because they have great potential for use in regenerative medicine to repair and regenerate damaged tissues. The International Society for Cellular Therapy has proposed a guideline for defining MSCs, in which MSCs must exhibit plastic adherent properties in standard culture conditions, exhibit trilineage mesodermal differentiation capacity in vitro, express specific markers (CD105, CD73, and CD90), and lack the expression of hematopoietic markers (CD14, CD 11b, CD34, CD45, CD19, CD 79a, and human leucocyte antigen DR (HLA-DR) surface molecules) (Dominici et al. 2006).

In addition, from the perspective of sustainability, MSCs are in abundance in the body and easily isolated from the human body with a less invasive procedure or from direct isolates derived from the biological waste such as neonatal birth-associated tissues and menstrual blood. Furthermore, as a source of stem cells, the use of MSCs has lesser ethical or risk implications than that of embryonic stem cells and induced pluripotent stem cells
(Leow et al. 2015). They are also more genomically stable than induced pluripotent stem cells (Andrews et al. 2017; Chen et al. 2014; Lamm et al. 2016; Paula et al. 2015; Scheers et al. 2013).

MSCs were first isolated from bone marrow (Pittenger et al. 1999), and later from various human tissues, such as adipose tissues (Wagner et al. 2005), synovia (Lee et al. 2011), human peripheral blood (Ab Kadir et al. 2012), menstrual blood from the endometrial lining (Allickson et al. 2011), human placenta (Vellasamy et al. 2012) and Wharton's Jelly of the umbilical cord (Hou et al. 2009).

Amongst these MSC sources, Wharton's jellyderived mesenchymal stem cells (WJ-MSCs) have several advantages over MSCs from other sources. WJMSCs ability to differentiate into adipocytes, osteocytes, and cardiomyocytes has been established (Wang et al. 2004). In a previous study, WJ-MSCs require shorter population doubling time than typical MSCs (Shaer et al. 2014). In addition to having the most rapid growth rate, WJ-MSCs also exhibited the strongest osteogenic differentiation ability, compared to bone marrow-derived, adipose tissuederived, and placenta-derived MSCs (Li et al. 2014).

Tse et al. (2003) had proposed that MSCs are immune-privileged because allogeneic MSCs failed to stimulate the activation of peripheral blood mononuclear cells (PBMCs). Following that, researchers proposed that MSCs are immune-evasive as they express low levels 
of major histocompatibility complex class I (MHC I) molecules, lack MHC II, secreted interferon-gamma (IFN- $\gamma$ ), and indoleamine 2,3-dioxygenase (IDO); they suppressed allogeneic $\mathrm{T}$ cell proliferation, and regulatory T cells, as well as inhibit natural killer (NK) cell-mediated cytolysis (Kim et al. 2018). HLA-G, a MHC class I molecule, are known to be expressed in the placental tissues to mediate immunotolerance between fetus and the mother. It has been reported to be expressed in MSCs from various sources, such as bone marrow, adipose tissue, and decidua (Ivanova-Todorova et al. 2009), thus provided the notion that MSCs were immune privileged. High levels of HLA-G were proven to protect MSCs against NK cell-mediated cytolysis (Selmani et al. 2008; Wang et al. 2011) and inhibit T-cell proliferation in vitro (Kim et al. 2018). Interestingly, WJ-MSCs displayed more prominent HLA-G-induced inhibitory effects than other sources of MSCs (Kim et al. 2018). It was further shown that co-culture of WJ-MSCs and allogeneic human PBMCs in vitro upregulates HLA-G expression in WJ-MSCs (Ding et al. 2016; Lee et al. 2014).

Currently, it is well established that MSCs exert their immunosuppressive effect through several mechanisms, including the suppression of innate and adaptive immune cell activities via the interaction of cytokines, surface molecules, and receptors (Bartholomew et al. 2002; Deng et al. 2016; Glenn \& Whartenby 2014; Guerrouahen et al. 2019; Weiss \& Dahlke 2019). MSCs also mediate monocyte polarization (Abumaree et al. 2013; Cho et al. 2014). Monocytes are dormant cells that differentiate into either M1 or M2 macrophages, depending on the stimuli. Studies show that MSCs can regulate the transformation of M1 macrophage to M2 macrophages (promptly toward antiinflammation properties) via prostaglandin E2 (Ylöstalo et al. 2012). Hence, MSCs immunomodulatory role in regulating inflammation have been proposed (Bernardo \& Fibbe 2013; Qu et al. 2018), which currently have been applied in clinical trials of immune-related diseases such as Crohn's disease, multiple sclerosis, systemic lupus erythematosus, type-1 diabetes and graft-versus-host disease (Wang et al. 2018).

MSCs have also been induced to commit to specific lineage before implantation. Such strategy has been adopted by our team for constructing tissue-engineered grafts such as bone ( $\mathrm{Ng}$ et al. 2014), cartilage (Ude et al. 2015) and nerve (Ramli et al. 2019). Liu et al. (2006) showed that MSCs retained their immune-privileged and immunomodulatory properties even after osteogenic differentiation. However, the immunomodulatory properties are lost post-implantation. In a HLA mismatched setting, osteodifferentiated MSCs from bone marrow and adipose tissues showed enhanced HLA-G expression, which further increased in inflammatory conditions after the addition of IFN- $\gamma$ and tumor necrosis factor-alpha (TNF- $\alpha$ ) (Montespan et al. 2014). In another study, immune-related molecules, such as B7-H3 (CD276) and HLA-E, which are characteristic of naive MSCs, were found to be expressed in differentiated progeny, suggesting the maintenance of immune-privileged properties after differentiation into more mature phenotypes (La et al. 2013).

In our previous studies, the proliferation rate and osteogenic potential of human WJ-MSCs was studied among three anatomical regions of the umbilical cord, and the results showed that middle segment showed the lowest proliferation rate and differentiation potential in vitro while the maternal segment resulted in greater osteogenesis than the middle segment in vivo (Lim et al. 2018, 2016). However, the immunomodulation potential of WJ-MSCs from three different anatomical segments has never been compared. Thus, this study aimed to investigate the immunomodulatory properties of WJ-MSCs derived from three anatomical segments and compare their immunomodulatory properties before and after osteodifferentiation.

\section{MATERIALS AND METHODS}

\section{ISOLATION AND EXPANSION OF WHARTON'S JELLY MESENCHYMAL STEM CELLS}

The uses of umbilical cord from human subjects are approved by Universiti Kebangsaan Malaysia Research Ethics Committee. Umbilical cord samples were collected from a consented healthy donor whose pregnancies were uneventful and free from complications such as pre-eclampsia, gestational Diabetes Mellitus (GDM), anaemia, infectious disease, and foetal anomaly. Samples were collected from pregnancies of 38 weeks and above and delivered via caesarean section (e.g. at least two previous scars, failed external cephalic version for breech presentation, and asymptomatic placenta previa). The whole length of the umbilical cord was identified; umbilical cord segment measuring $3 \mathrm{~cm}$ each was cut from three different segments: $3 \mathrm{~cm}$ from fetus (fetal), $3 \mathrm{~cm}$ from placenta (maternal) and $3 \mathrm{~cm}$ of midpoint (middle). Collected samples were processed in Tissue Engineering Centre at Universiti Kebangsaan Malaysia Medical Centre within $24 \mathrm{~h}$ after collection. The segmented cords were handled in the aseptic method and processed in Biological Safety Cabinet and Laminar Flow Cabinet. Bloodstains were removed by rinsing the cord with 
sterile Dulbecco's Phosphate-Buffered Saline (DPBS) (Gibco-Invitrogen, NY, USA). After blood vessels were removed, the cords were cut and minced into smaller pieces approximately $1 \mathrm{~mm}^{3}$ in size by using a sterile blade in a petri dish. The WJ-MSCs were harvested by using enzymatic digestion method as described previously (Lim et al. 2016). Cells from passage four (P4) to passage eight (P8) were used for subsequent assays and procedure.

\section{DIFFERENTIATION OF MESENCHYMAL STEM CELLS INTO OSTEOGENIC LINEAGE}

Cell culture of passage three with cell confluency of $80 \%$ was selected for differentiation into the osteogenic lineage. The previous medium was removed and osteogenic medium consisting of Minimum Essential Medium (Gibco-Invitrogen), 0.002\% Dexamethasone (St.Louis MO), $0.5 \% \beta$-glycerophosphate (Sigma-Aldrich), 1\% ascorbic acid (Sigma Aldrich) was added. The osteogenic medium was changed every three to four days for three weeks to induce osteodifferentiation. Cells were incubated at $37{ }^{\circ} \mathrm{C}$ in a humidified atmosphere with $5 \% \mathrm{CO}_{2}$. Osteodifferentiation was confirmed morphologically under microscope and mineralization (calcium deposits) was detected by alizarin red staining.

\section{DETECTION OF HUMAN LEUCOCYTE ANTIGEN AND SURFACE MARKER OF MSCS}

A total of $2 \times 10^{5}$ cells from each segment of undifferentiated and osteodifferentiated WJ-MSCs (P4-P8) were resuspended in $500 \mu \mathrm{L}$ DPBS and stained with $20 \mu \mathrm{L}$ of anti-HLA-DR (BD-Pharmingen ${ }^{\mathrm{TM}}$ ), anti-HLA ABC (BDPharmingen ${ }^{\mathrm{TM}}$ ) and anti-HLA G (eBioscience) separately. $2 \times 10^{5}$ WJ-MSCs were also stained with $10 \mu \mathrm{L}$ antiCD10, anti-CD105, anti-CD29, anti-CD34, anti-CD44, anti-CD45 and anti-CD90 to measure the expression of those markers. The cells were incubated for $30 \mathrm{~min}$ and detection was performed by using BD FACSCalibur Flow Cytometer.

\section{ISOLATION OF PERIPHERAL BLOOD MONONUCLEAR CELLS (PBMCS)}

Peripheral blood was taken from a healthy consented donor. About $60 \mathrm{~mL}$ was taken and heparinized. The PBMCs was extracted by using Ficoll-Hypaque Gradient Centrifugation Technique. Fresh heparinized blood was diluted with DPBS in 1:1 ratio. Ficoll-Paque ${ }^{\mathrm{TM}}$ PLUS (GE Healthcare Life Sciences) was placed at the bottom of $15 \mathrm{~mL}$ conical centrifugation tube, subsequently; blood/ PBS mixture was carefully layered over the Ficoll-Paque solution. Four mL of Ficoll-Paque solution was used for every $10 \mathrm{~mL}$ of blood/DPBS mixture. After that, the tube was centrifuged at $400 \times \mathrm{g}$ for $30 \mathrm{~min}$ at room temperature in a swinging-bucket rotor with brake off. After centrifugation, the tube was carefully removed to prevent disruption of the interface. PBMCs were identified as the layer in Ficoll-plasma interface. Then, the PBMCs were carefully aspirated and washed with DPBS twice.

Next, PBMCs were re-suspended into $5 \mathrm{~mL}$ Roswell Park Memorial Institute (RPMI) medium 1640 (Gibco, USA) with $10 \%$ heat-inactivated human serum for subsequent assay or procedure. The cells were counted using haemocytometer by mixing cell suspension with trypan blue solution in 9:1 ratio.

\section{PROLIFERATION OF PBMCS CO-CULTURED WITH} UNDIFFERENTIATED AND OSTEODIFFERENTIATED WJMSCS

To evaluate the PBMCs proliferation during coculture with WJ-MSCs, PBMCs were labelled with carboxyfluorescein succinimidyl ester (CFSE) before co-culture with WJ-MSCs. $100 \mu \mathrm{g}$ vial of CFSE stock solution (BioLegend; Cat\#422701) was reconstituted with anhydrous Dimethyl Sulfoxide to yield a stock concentration of $5 \mathrm{mM}$. First, thoroughly resuspended PBMCs in $1 \mathrm{~mL}$ of DPBS placed carefully in the bottom of a $15 \mathrm{~mL}$ falcon tube. Meanwhile, $0.55 \mu \mathrm{L}$ of the $5 \mathrm{mM}$ stock of CFSE was diluted in $110 \mu \mathrm{L}$ PBS in a microcentrifuge tube. Then, the CFSE/DPBS solution was homogenized with $1 \mathrm{~mL}$ of cells suspension quickly and vortex well to ensure uniform mixing of the solution. The cells were incubated for $5 \mathrm{~min}$ at room temperature in a dark environment by covering the tube with aluminium foil. The cells were washed in $10 \mathrm{~mL}$ of ice-cold DPBS containing $5 \%$ human serum by centrifuged at $300 \times \mathrm{g}$ for $5 \mathrm{~min}$. The supernatant was discarded and the pellet was washed twice with DPBS. To produce activated PBMCs (aPBMCs), $3 \times 10^{5}$ PBMCs were stimulated with $10 \mu \mathrm{g} / \mathrm{mL}$ lipopolysaccharide (LPS) (Sigma-Aldrich) for 5 days. In this study, activated PBMCs were used as positive control and non-activated PBMCs were used as negative control.

Undifferentiated and osteodifferentiated WJ-MSCs (P4-P8) from three different anatomical regions (i.e. fetal, middle \& maternal) were seeded in 24 -well plates at $5 \times 10^{4}$ cells per well. The experiment was performed in triplicates. After WJ-MSCs had attached to the wells after three to five days. Then, WJ-MSCs were co-cultured with $3 \times 10^{5}$ pre-labelled PBMCs in each well for five days. On day five, PBMCs from the co-culture were stained with 7-Amino-actinomycin D (7AAD) (BD Via-Probe 
TM) according to manufacturer's recommendation. Cells from the culture wells were harvested and centrifuged at $300 \times \mathrm{g}$ for $5 \mathrm{~min}$. The supernatant was discarded and the pellet was re-suspended in $200 \mu \mathrm{L}$ of DPBS. Then, 20 $\mu \mathrm{L}$ of 7AAD was added and incubated for $10 \mathrm{~min}$. The parent and daughter PBMCs can be recognised by flow cytometry (BD FACSCalibur). Region R1 which represents the proliferating PBMCs population was gated to calculate the percentage of proliferating PBMCs using the formula below:

Percentage of proliferating PBMCs $=\frac{\text { Number of events in R } 1}{\text { Number of total events }} \times 100$

\section{STATISTICAL ANALYSIS}

All the experiments were conducted in triplicate and unpaired student t-test was used to analyse the data.

\section{RESULTS}

\section{WJ-MSCS AND OSTEODIFFERENTIATED WJ-MSCS SHARE} SIMILAR HLA PHENOTYPE

WJ-MSCs were successfully isolated and cultured on a standard medium (Figure 1(a)), and at passage four, the cells were induced into osteogenic lineage for approximately three weeks (Figure 1(b)). Osteogenesis was observed, evidenced by the positive calcium deposition with alizarin Red staining (Figure 1(c)). Surface marker characterization was performed for both WJ-MSCs and osteodifferentiated WJ-MSCs. Standard MSC surface markers were expressed in WJ-MSCs and were conserved in osteodifferentiated WJ-MSCs, with only a slight reduction in expression of CD105 after osteodifferentiation (Table 1).

(a)

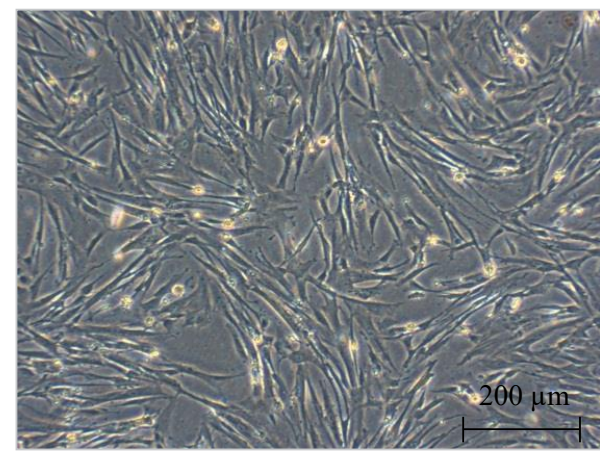

(b)

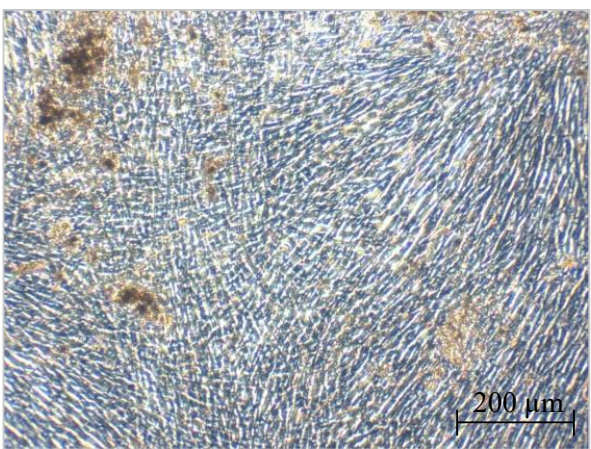

(c)

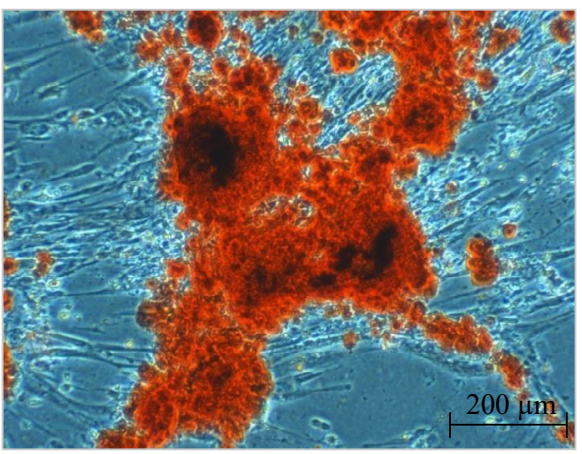

FIGURE 1. (a) Undifferentiated WJ-MSCs (b) Osteodifferentiated WJMSCs (c) WJ-MSCs stained with alizarin red for osteogenesis 
TABLE 1. Surface marker characterization of MSCs and osteodifferentiated MSCs by flow cytometry

\begin{tabular}{lcc}
\hline Surface markers & MSCs & Osteodifferentiated MSCs \\
\hline CD10 & $97.82 \%$ & $97.84 \%$ \\
CD105 & $98.95 \%$ & $93.58 \%$ \\
CD29 & $99.8 \%$ & $99.97 \%$ \\
CD34 & $4.42 \%$ & $1.54 \%$ \\
CD44 & $99.56 \%$ & $99.21 \%$ \\
CD45 & $0.45 \%$ & $0.16 \%$ \\
CD90 & $100 \%$ & $99.98 \%$ \\
\hline
\end{tabular}

\section{EXPRESSION OF HLA PROFILE ON WJ-MSCS AND OSTEODIFFERENTIATED WJ-MSCS}

The HLA profile of each sample was quantified using flow cytometry. The minimal expression of HLA-DR was maintained in WJ-MSCs before and after differentiation with the mean values of $1.76 \%$ and $0.25 \%$, respectively. For segment comparison, the mean values of fetal, middle, and maternal WJ-MSCs were $2.24 \%, 2.81 \%$, and $0.22 \%$, respectively; whereas those for osteodifferentiated WJ-MSC segments were $0.09 \%, 0.32 \%$, and $0.35 \%$, respectively. Thus, a minimal level of HLA-DR was also maintained for every segment (Figure 2(a)). The mean values for the expression of HLA-ABC for WJ-MSCs and osteodifferentiated WJ-MSCs were $55.83 \%$ and $49.16 \%$, respectively. Fetal, middle, and maternal segments from MSCs had mean values of $52.36 \%, 47.78 \%$, and $67.34 \%$, respectively. For osteodifferentiated WJ-MSCs, fetal, middle, and maternal segments had mean values of $60.66 \%, 39.46 \%$, and $47.17 \%$, respectively (Figure $2(\mathrm{~b})$ ). The HLA-G profiles of MSCs and osteodifferentiated WJMSCs were expressed at $26.17 \%$ and $23.47 \%$, respectively. The HLA-G expressions by fetal, middle, and maternal segments from MSCs were $31.6 \%, 28.52 \%$, and $18.38 \%$, respectively; whereas fetal, middle, and maternal segments from osteodifferentiated WJ-MSCs were $22.68 \%, 14.97 \%$, and $32.76 \%$, respectively (Figure 2(c)).

(a)

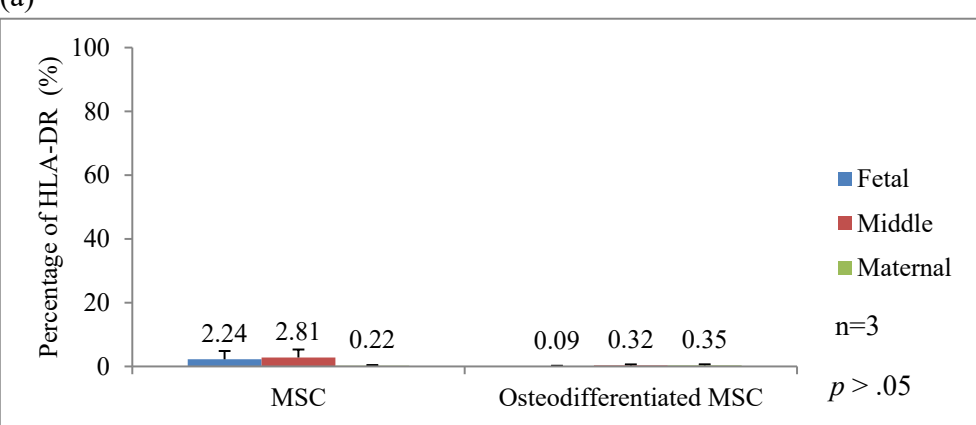

(b)

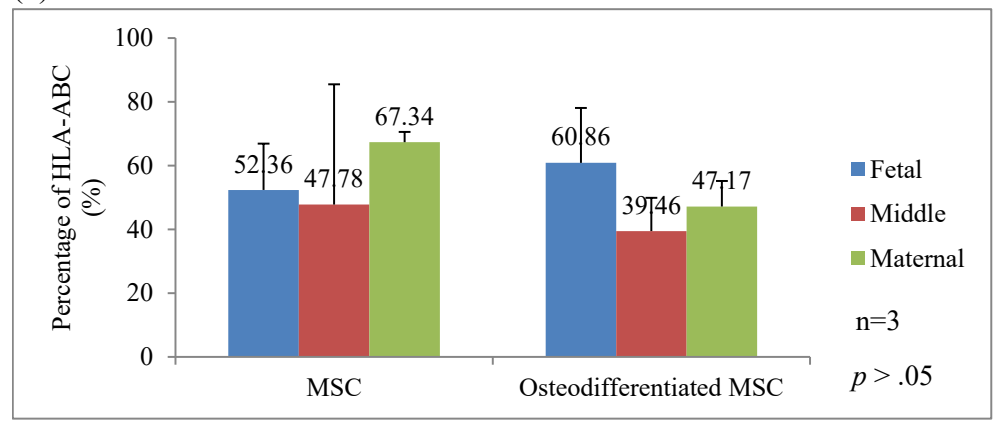


(c)

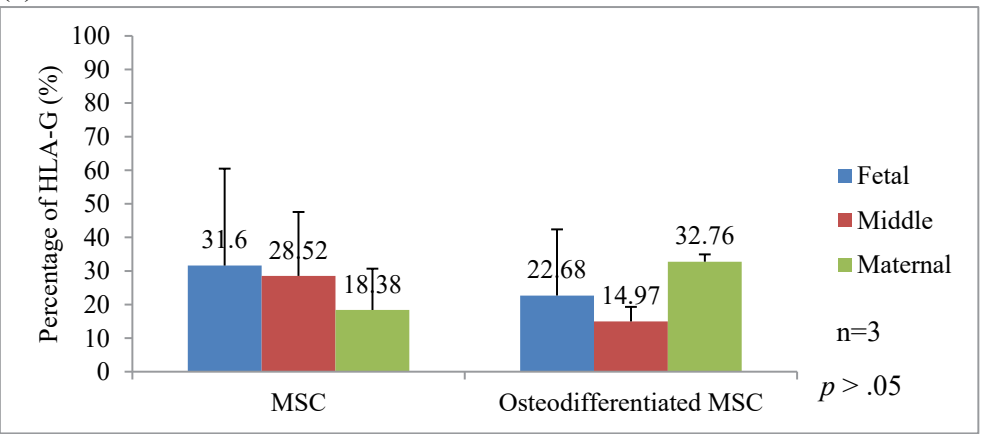

FIGURE 2. HLA profile of WJ-MSCs and osteodifferentiated WJ-MSCs for each segment. (a) HLA-DR expression, (b) HLA-ABC expression, and (c) HLA-G expression. No significant changes were observed on the HLA expression of MSCs before and after osteodifferentiation

\section{LYMPHOCYTE PROLIFERATION ASSAY}

To test for the immune-privileged and immunosuppressive properties of allogeneic WJ-MSCs, we co-cultured nonactivated PBMCs or LPS-stimulated PBMCs (activated PBMCs; aPBMCs) and WJ-MSCs in 1:6 ratios for five days (Figure 3). Under unstimulated conditions, the percentages of proliferating PBMCs in each segment of undifferentiated WJ-MSCs were $6.01 \%$ (fetal), $8.66 \%$ (middle), and $9.1 \%$ (maternal); whereas for osteodifferentiated WJ-MSCs, the percentages of proliferating PBMCs were $8.79 \%$ (fetal), 7.1\% (middle), and $5.63 \%$ (maternal). Therefore, for unstimulated conditions, osteodifferentiated WJ-MSCs were less immunogenic than undifferentiated MSCs $(p<.05)$ (Figure 4(a)). Histogram from day 1 to day 5 showed a reduction in the intensity of intracellular CFSE dye.

Under stimulated conditions, the proliferation percentages of aPBMCs in the fetal, middle, and maternal segments of undifferentiated WJ-MSCs were 5.17\%, 7.59\%, and $7.24 \%$, respectively; whereas for osteodifferentiated WJ-MSCs, the proliferation percentages of aPBMCs were $4.98 \%$ (fetal), $4.15 \%$ (middle), and $4.84 \%$ (maternal). Thus, under stimulated conditions, osteodifferentiated WJ-MSCs were less immunogenic than undifferentiated MSCs $(p<.001)$ (Figure 4(b)).

Furthermore, both undifferentiated and osteodifferentiated WJ-MSCs were less immunogenic in stimulated conditions than in unstimulated conditions $(p<.05)$. The percentage of proliferating PBMCs in undifferentiated WJ-MSCs was $7.93 \%$ when unstimulated and $6.67 \%$ when stimulated with LPS. Whereas the percentage of proliferating PBMCs in osteodifferentiated WJ-MSCs was $7.18 \%$ under unstimulated and $4.66 \%$ under simulated conditions (Figure 5).
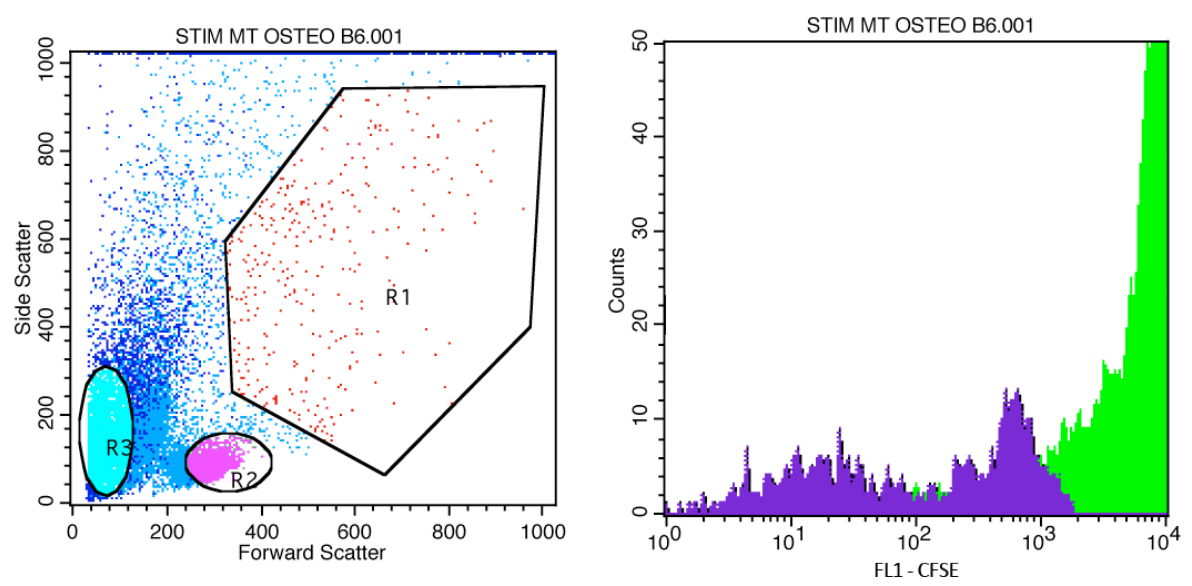

FIGURE 3. Representative dot plot and histogram for lymphocyte proliferation assay a) Three populations of PBMCs namely, proliferating PBMC population (R1), resting PBMC population (R2), and debris (R3), were gated. The R1-gated FL1-CFSE histogram represents the expression of CFSE on day 1 (green) and day 5 (purple). Shifting of the histogram from day 1 to day 5 showed a reduction in the intensity of intracellular CFSE dye, indicating the proliferation of PBMCs resulting in daughter cells with lower intensity 


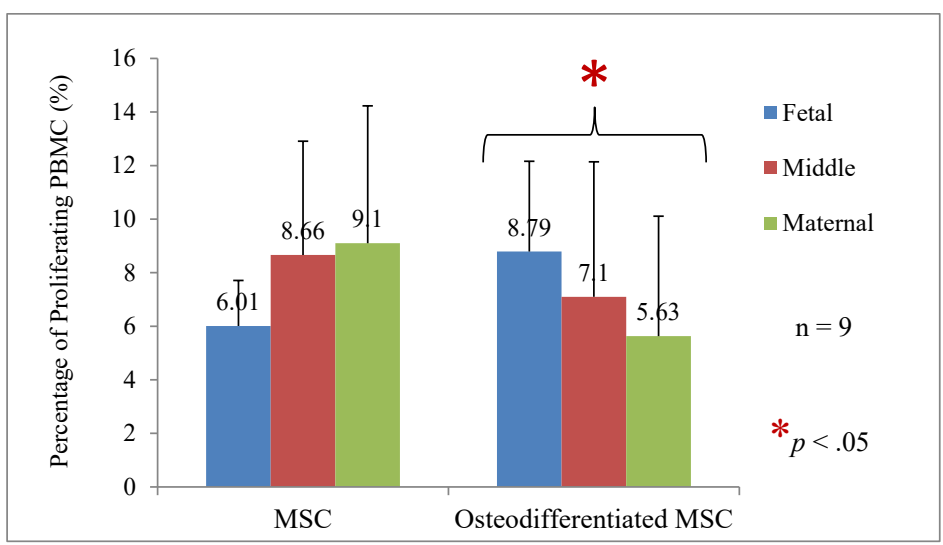

b)

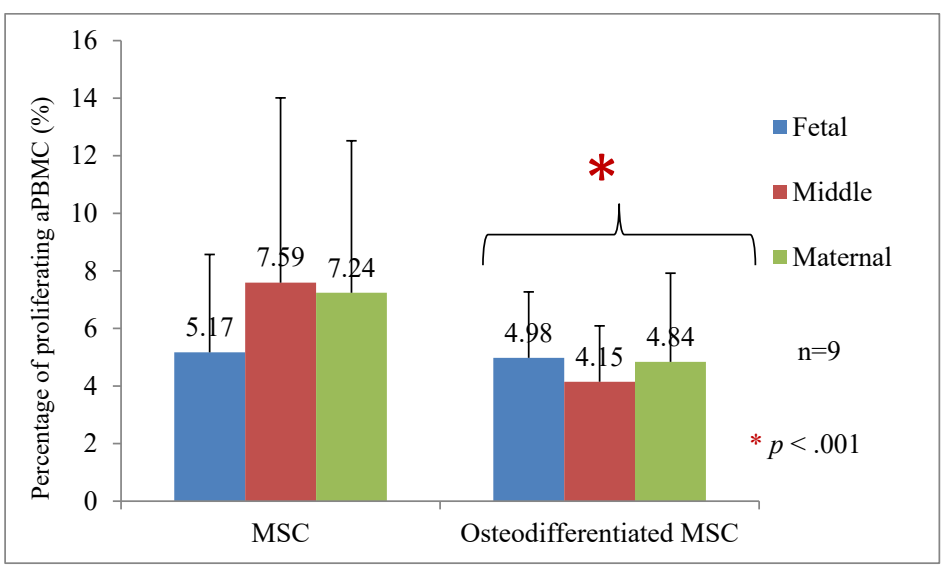

FIGURE 4. The bar graph shows the immunogenicity of undifferentiated and osteodifferentiated WJ-MSCs with (a) PBMC and (b) aPBMC. The significant analysis of data was performed by combining three anatomical segments of MSCs and compared between osteodifferentiated and undifferentiated WJ-MSCs. Osteodifferentiated WJ-MSCs were less immunogenic than undifferentiated WJMSCs in both PBMCs $(p<.05)$ and aPBMCs $(p<.001)$

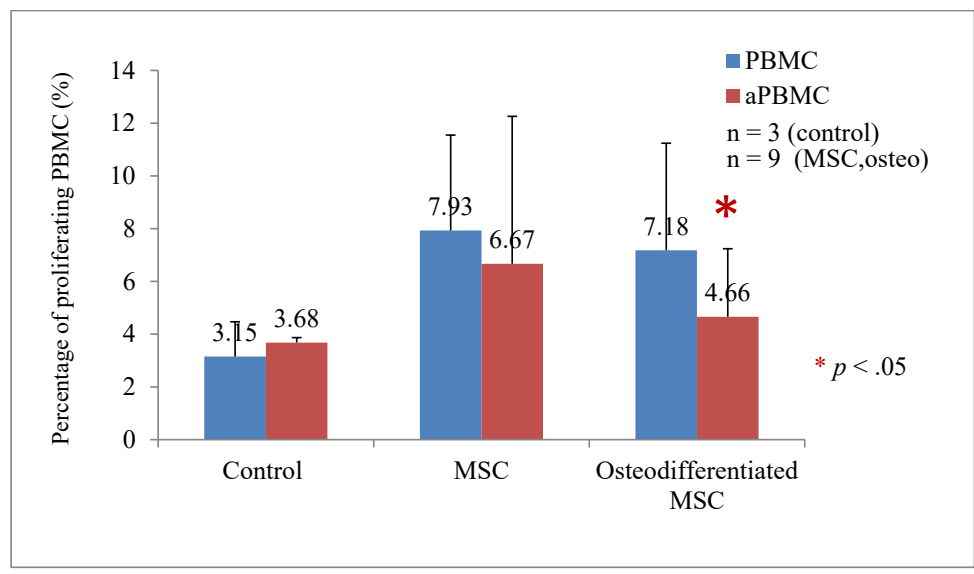

FIGURE 5. The graph shows the immunogenicity of undifferentiated and osteodifferentiated WJ-MSCs in a co-culture of PBMCs and aPBMCs. In the osteodifferentiated WJ-MSC and allogeneic PBMC co-culture, the reduction in immunogenicity is even more profound with aPBMCs than with non-activated PBMCs $(p<.05)$ 


\section{DISCUSSION}

This study aimed to investigate whether the immunomodulatory properties of WJ-MSCs differ between WJ-MSCs from different segments of umbilical cords and between osteodifferentiated and undifferentiated WJ-MSCs as well as whether the difference, if any, can be correlated with its HLA profile. Our result showed that there was no significant difference in HLA profile (HLA-ABC, HLA-DR and HLA-G) between three anatomical segments of WJ-MSCs and also between the undifferentiated and osteodifferentiated WJ-MSCs. There is no significant difference in proliferation rate of $\mathrm{PBMC}$ or aPBMC observed between three different anatomical segments of WJ-MSCs. Interestingly, we found that either differentiated or non-differentiated WJ-MSCs are not immune-privileged but osteodifferentiated WJ-MSCs elicit lesser the immune response of aPBMC (reflected by the proliferation percentage of aPBMCs) compared to non-activated PBMC. This result was supported by the study of Montespan et al. (2014), which also showed that the HLA-G expression is maintained after WJ-MSCs differentiation. They found that undifferentiated and oestodifferentiated MSCs can reduce PBMC proliferation as similarly observed in this study.

In terms of HLA-ABC and HLA-DR expression after osteodifferentiation, our findings contradicted that Le Blanc et al. (2003) indicated that HLA-ABC expression increases after osteodifferentiation. The study also addressed that osteodifferentiated WJ-MSCs are hypoimmunogenic (do not stimulate the immune response) and possess immunomodulation properties by suppressing the proliferation of PBMCs, especially in oesteodifferentiated WJ-MSCs. The immunomodulation property of WJ-MSCs after osteodifferentiation was probably mediated via other mechanisms other than HLA molecules or surface markers. This is because the expression of surface markers of WJ-MSCs was slightly decreased in CD34, CD45 and CD105 after oesteodifferentiation (Table 1). CD34 and CD45 are lineage-specific marker for hematopoietic stem cell (Ema et al. 2004; Rheinländer et al. 2018); the reduction of haematopoietic stem cell surface markers was observed after WJ-MSCs differentiation. CD105 is a common marker for MSCs; lack of evidence to show the expression of CD105 in WJ-MSCs affecting the immunomodulation properties WJ-MSCs.

Interestingly, other surface markers such as CD10, CD29, CD44, and CD90 are conserved after WJ-MSCs differentiation. We postulated that the immunomodulation properties of oesteodifferentiated WJ-MSCs are retained due to the preservation of surface markers. A study supports our hypothesis that the inactivated or dead MSCs also maintain their immunomodulatory abilities via surface markers rather than via their secreted cytokines (Luk et al. 2016).

Although immunomodulatory capacity may depend on surface markers, previous studies have reported that MSCs exerts its immunosuppressive effect via both cellto-cell contact and soluble factors (Ren et al. 2008; Weiss et al. 2008). In a seminal study by Di Nicola et al. (2002), MSCs were shown to inhibit allogeneic T-cell proliferation with and without the presence of an immune stimulant/activator. The group further demonstrated that MSCs separated by a transwell membrane from T-cells in a co-culture, maintain their inhibitory effect on T-cell proliferation indicating that MSCs also exerted their immunosuppressive effect by releasing soluble factors. Soluble factor, such as indoleamine 2,3-dioxygenase (IDO), prostaglandin (PGE2), transforming growth factor (TGF- $\beta 1$ ), nitric oxide (NO), hepatocyte growth factor (HGF), interleukin-6 (IL-6), IL-10, semaphorin-3A, galectin-1 (Gal-1) and Gal-9 were subsequently proven to be involved in the T-cell inhibition by MSCs (Meisel et al. 2004).

MSCs were shown to secrete high levels of several leukocyte chemokines such as chemokines (C-X-C motif) ligand 9 (CXCL9), CXCL10, and CXCL11 which acted as chemoattractant for T-cells so that the T-cells could be suppressed by MSC when in close proximity. The neutralization of CXCR3, a receptor for the T-cell chemokine CXCL9, -10 , and -11 , reverted immunosuppression by MSCs, showing the importance of T-cell chemotaxis in MSC-mediated immunity (Ren et al. 2008). Besides, other molecules such as vascular cell adhesion protein 1 (VCAM-1), intercellular adhesion molecule 1 (ICAM-1), and programmed cell death protein 1 (PD-1), have been described to participate in T-cell suppression by MSCs (Ren et al. 2010).

Attenuation of the immunogenicity of implanted MSCs is one of the main priorities in tissue engineering research. We have demonstrated a possible approach for minimizing the immunogenicity of MSCs by inducing osteogenic differentiation in MSCs. These data suggest that osteogenically-differentiated WJ-MSCs are less immunogenic than undifferentiated WJ-MSCs. According to a similar study, osteogenically-differentiated WJ-MSCs derived from bone marrow display an immunosuppressive effect on PBMCs by secreting more IL-10 and TGF- $\beta$, unlike undifferentiated MSCs (Liu et al. 2006). 
This study has its limitations. Only three biological samples were analyzed in this study. The study should be verified with larger sample size in future. In this study, stimulation with LPS at a relatively high concentration resulted in a weak activation of T-cell proliferation, hence other stronger mitogens such as phytohemagglutinin (PHA), interleukin-2 (IL-2) or anti-CD3/CD28 beads should be used in the future. As mixed lymphocytes were used in this study, we could not rule out the interplay between different populations of lymphocytes especially upon activation with the stimulant. Hence, it is recommended that future experimentations to be carried out with purified fraction of $\mathrm{T}, \mathrm{NK}$, and $\mathrm{B}$ cells so that the immunomodulatory effect of MSCs on the respective lymphocyte subpopulation can be elucidated. We also recommend that immunomodulatory properties for other WJ-MSC-derived lineages, such as adipogenic and chondrogenic lineages be investigated. Subsequently, the soluble factors responsible for the immunomodulatory properties of WJ-MSCs will need to be identified.

\section{CONCLUSION}

WJ-MSCs are not immune-privileged but immuneevasive to PBMCs. No statistically significant difference could be established in immunomodulatory properties among WJ-MSCs derived from different segments of the umbilical cord. Osteodifferentiated WJ-MSCs showed lesser immunogenicity than undifferentiated WJ-MSCs. The reduction in immunogenicity of osteodifferentiated WJ-MSCs is even more pronounced in activated PBMC cocultured conditions. Hence, allogenic osteodifferentiated WJ-MSCs can be further explored as a potential off-theshelf product for bone regeneration.

\section{ACKNOWLEDGEMENTS}

This study was funded by Universiti Kebangsaan Malaysia (UKM) fundamental grant, (FF-2015-180). We would like to acknowledge all the staff and postgraduate students of Centre for Tissue Engineering \& Regenerative Medicine (CTERM) for the full support and guidance throughout our study. Appreciation goes to the Cell Transplantation Unit, Blood Bank Unit and the staff from the Obstetrics and Gynaecology operating theatre of Universiti Kebangsaan Malaysia Medical Centre (UKMMC)

\section{REFERENCES}

Ab Kadir, R., Zainal Ariffin, S.H., Abdul Wahab, R.M., Kermani, S. \& Senafi, S. 2012. Characterization of mononucleated human peripheral blood cells. The Scientific World Journal 2012: 843843 .
Abumaree, M.H., Al Jumah, M.A., Kalionis, B., Jawdat, D., Al Khaldi, A., Abomaray, F.M., Fatani, A.S., ChamLey, L.W. \& Knawy, B.A. 2013. Human placental mesenchymal stem cells (PMSCs) play a role as immune suppressive cells by shifting macrophage differentiation from inflammatory M1 to anti-inflammatory M2 macrophages. Stem Cell Reviews and Reports 9(5): 620-641.

Allickson, J.G., Sanchez, A., Yefimenko, N., Borlongan, C.V. \& Sanberg, P.R. 2011. Recent studies assessing the proliferative capability of a novel adult stem cell identified in menstrual blood. The Open Stem Cell Journal 3: 4-10.

Andrews, P.W., Ben-David, U., Benvenisty, N., Coffey, P., Eggan, K., Knowles, B.B., Nagy, A., Pera, M., Reubinoff, B., RuggGunn, P.J. \& Glyn, N.S. 2017. Assessing the safety of human pluripotent stem cells and their derivatives for clinical applications. Stem Cell Reports 9(1): 1-4.

Bartholomew, A., Sturgeon, C., Siatskas, M., Ferrer, K., McIntosh, K., Patil, S., Hardy, W., Devine, S., Ucker, D., Deans, R., Moseley, A. \& Hoffman, R. 2002. Mesenchymal stem cells suppress lymphocyte proliferation in vitro and prolong skin graft survival in vivo. Experimental Hematology 30(1): 42-48.

Bernardo, M.E. \& Fibbe, W.E. 2013. Mesenchymal stromal cells: Sensors and switchers of inflammation. Cell Stem Cell 13(4): 392-402.

Chen, G., Yue, A., Ruan, Z., Yin, Y., Wang, R., Ren, Y. \& Zhu, L. 2014. Human umbilical cord-derived mesenchymal stem cells do not undergo malignant transformation during long-term culturing in serum-free medium. PLOS ONE 9(6): e98565.

Cho, D., Kim, M.R., Jeong, H., Jeong, H.C., Jeong, M.H., Yoon, S.H., Kim, Y.S. \& Ahn, Y. 2014. Mesenchymal stem cells reciprocally regulate the M1/M2 balance in mouse bone marrow-derived macrophages. Experimental and Molecular Medicine 46(1): e70.

Deng, Y., Zhang, Y., Ye, L., Zhang, T., Cheng, J., Chen, G., Zhang, Q. \& Yang, Y. 2016. Umbilical cord-derived mesenchymal stem cells instruct monocytes towards an IL10-producing phenotype by secreting IL6 and HGF. Scientific Reports 6: 37566.

Di Nicola, M., Carlo-Stella, C., Magni, M., Milanesi, M., Longoni, P.D., Matteucci, P., Grisanti, S. \& Gianni, A.M. 2002. Human bone marrow stromal cells suppress T-lymphocyte proliferation induced by cellular or nonspecific mitogenic stimuli. Blood 99(10): 3838-3843.

Ding, D.C., Chou, H.L., Chang, Y.H., Hung, W.T., Liu, H.W. \& Chu, T.Y. 2016. Characterization of HLA-G and related immunosuppressive effects in human umbilical cord stroma-derived stem cells. Cell Transplantation 25(2): 217-228.

Dominici, M., Le Blanc, K., Mueller, I., Slaper-Cortenbach, I., Marini, F., Krause, D., Deans, R., Keating, A., Prockop, D. \& Horwitz, E. 2006. Minimal criteria for defining multipotent mesenchymal stromal cells. The International Society For Cellular Therapy position statement. Cytotherapy 8(4): 315-317. 
Ema, H., Morita, Y. \& Nakauchi, H. 2004. Handbook of Stem Cells Vol. 2: Phenotype of Mouse Hematopoietic Stem Cells. New York: Elsevier Academic Press.

Glenn, J.D. \& Whartenby, K.A. 2014. Mesen chymal stem cells: Emerging mechanisms of immunomodulation and therapy. World Journal of Stem Cells 6(5): 526-539.

Guerrouahen, B.S., Sidahmed, H., Al Sulaiti, A., Al Khulaifi, M. \& Cugno, C. 2019. Enhancing mesenchymal stromal cell immunomodulation for treating conditions influenced by the immune system. Stem Cells International 2019: 7219297.

Hou, T.Y., Xu, J.Z., Wu, X.H., Xie, Z., Luo, F., Zhang, Z.H. \& Zeng, L. 2009. Umbilical cord Wharton's jelly: A new potential cell source of mesenchymal stromal cells for bone tissue engineering. Tissue Engineering Part A 15(9): 23252334.

Ivanova-Todorova, E., Mourdjeva, M., Kyurkchiev, D., Bochev, I., Stoyanova, E., Dimitrov, R., Timeva, T., Yunakova, M., Bukarev, D., Shterev, A., Tivchev, P. \& Kyurkchiev, S. 2009. HLA-G expression is up-regulated by progesterone in mesenchymal stem cells. American Journal of Reproductive Immunology 62(1): 25-33.

Kim, J.H., Jo, C.H., Kim, H.R. \& Hwang, Y.I. 2018. Comparison of immunological characteristics of mesenchymal stem cells from the periodontal ligament, umbilical cord, and adipose tissue. Stem Cells International 2018: 8429042.

Lamm, N., Ben-David, U., Golan-Lev, T., Storchová, Z., Benvenisty, N. \& Kerem, B. 2016. Genomic instability in human pluripotent stem cells arises from replicative stress and chromosome condensation defects. Cell Stem Cell 18(2): 253-261.

La, R.G., Lo Iacono, M., Corsello, T., Corrao, S., Farina, F. \& Anzalone, R. 2013. Human Wharton's jelly mesenchymal stem cells maintain the expression of key immunomodulatory molecules when subjected to osteogenic, adipogenic and chondrogenic differentiation in vitro: New perspectives for cellular therapy. Current Stem Cell Research and Therapy 8(1): 100-113.

Le Blanc, K., Tammik, C., Rosendahl, K., Zetterberg, E. \& Ringdén, O. 2003. HLA expression and immunologic properties of differentiated and undifferentiated mesenchymal stem cells. Experimental Hematology 31(10): 890-896.

Lee, D.H., Joo, S.D., Han, S.B., Im, J., Lee, S.H., Sonn, C.H. \& Lee, K.M. 2011. Isolation and expansion of synovial CD34(-) CD44(+)CD90(+) mesenchymal stem cells: Comparison of an enzymatic method and a direct explant technique. Connective Tissue Research 52(3): 226-234.

Lee, M., Jeong, S.Y., Ha, J., Kim, M., Jin, H.J., Kwon, S.J., Chang, J.W., Choi, S.J., Oh, W., Yang, Y.S., Kim, J.S. \& Jeon, H.B. 2014. Low immunogenicity of allogeneic human umbilical cord blood-derived mesenchymal stem cells in vitro and in vivo. Biochemical and Biophysical Research Communications 446(4): 983-989.

Leow, S.N., Luu, C.D., Hairul Nizam, M.H., Mok, P.L., Ruhaslizan, R., Wong, H.S., Wan Abdul Halim, W.H., Ng,
M.H., Ruszymah, B.H.I., Chowdhury, S.R., Bastion, M.L. \& Then, K.Y. 2015. Safety and efficacy of human Wharton's Jelly-derived mesenchymal stem cells therapy for retinal degeneration. PLoS ONE 10(6): 1-20.

Li, X., Bai, J., Ji, X., Li, R., Xuan, Y. \& Wang, Y. 2014 Comprehensive characterization of four different populations of human mesenchymal stem cells as regards their immune properties, proliferation and differentiation. International Journal of Molecular Medicine 34(3): 695-704.

Lim, J., Razi, Z.R.M., Law, J.X., Nawi, A.M., Idrus, R., Chin, T.G., Mustangin, M. \& Ng, M.H. 2018. Mesenchymal stromal cells from the maternal segment of human umbilical cord is ideal for bone regeneration in allogenic setting. Tissue Engineering and Regenerative Medicine 15(1): 75-87.

Lim, J., Razi, Z.R., Law, J., Nawi, A.M., Idrus, R. \& Ng, M.H. 2016. MSCs can be differentially isolated from maternal, middle and fetal segments of the human umbilical cord Cytotherapy 18(12): 1493-1502.

Liu, H., Kemeny, D.M., Heng, B.C., Ouyang, H.W., Melendez, A.J. \& Cao, T. 2006. The immunogenicity and immunomodulatory function of osteogenic cells differentiated from mesenchymal stem cells. Journal of Immunology (Baltimore, Md. : 1950) 176(5): 2864-2871.

Luk, F., de Witte, S.F., Korevaar, S.S., Roemeling-van Rhijn, M., Franquesa, M., Strini, T., van den Engel, S., Gargesha, M., Roy, D., Dor, F.J., Horwitz, E.M., de Bruin, R.W., Betjes, M.G., Baan, C.C., Hoogduijn, M.J. 2016. Inactivated mesenchymal stem cells maintain immunomodulatory capacity. Stem Cells Development 25(18): 1342-1354.

Meisel, R., Zibert, A., Laryea, M., Göbel, U., Däubener, W. \& Dilloo, D. 2004. Human bone marrow stromal cells inhibit allogeneic t-cell responses by indoleamine 2,3-dioxygenasemediated tryptophan degradation. Blood 103(12): 46194621.

Montespan, F., Deschaseaux, F., Sensébé, L., Carosella, E.D. \& Rouas-Freiss, N. 2014. Osteodifferentiated mesenchymal stem cells from bone marrow and adipose tissue express HLA-G and display immunomodulatory properties in HLA-mismatched settings: Implications in bone repair therapy. Journal of Immunology Research 2014: 230346.

Ng, M.H., Duski, S., Tan, K.K., Yusof, M.R., Low, K.C., Rose, I.M., Mohamed, Z., Saim A. \& Idrus, R. 2014. Repair of segmental load-bearing bone defect by autologous mesenchymal stem cells and plasma-derived fibrin impregnated ceramic block results in early recovery of limb function. BioMed Research International 85(2): 301-312.

Paula, A.C., Martins, T.M., Zonari, A., Frade, S.P., Angelo, P.C., Gomes, D.A. \& Goes, A.M. 2015. Human adipose tissuederived stem cells cultured in xeno-free culture condition enhance c-MYC expression increasing proliferation but bypassing spontaneous cell transformation. Stem Cell Research and Therapy 6(1): 76.

Pittenger, M.F., Mackay, A.M., Beck, S.C., Jaiswal, R.K., Douglas, R., Mosca, J.D., Moorman, M.A., Simonetti, D.W., Craig, S. \& Marshak, D.R. 1999. Multilineage potential of adult human mesenchymal stem cells. Science 284(5411): 143-147. 
Qu, G., Xie, X., Li, X., Chen, Y., De Isla, N., Huselstein, C., Stoltz, J.F. \& Li, Y. 2018. Immunomodulatory function of mesenchymal stem cells: Regulation and application. Journal of Cellular Immunotherapy 4(1): 1-3.

Ramli, K., Aminath, I.G., Ahmad, A.A., Htwe, O., Mohamed Haflah, N.H., Law, Z.K., Hasan, S., Naicker, A.S., Mokhtar, S.A., Muhammad Ariffin, M.H., Baharuddin, A., Tan, G.C., Idrus, R., Abdullah, S. \& Ng, M.H. 2019. Efficacy of human cell-seeded muscle-stuffed vein conduit in rat sciatic nerve repair. Tissue Engineering Part A 25(19-20): 1438-1455.

Ren, G., Zhao, X., Zhang, L., Zhang, J., L'Huillier, A., Ling, W., Roberts, A.I., Le, A.D., Shi, S., Shao, C. \& Shi, Y. 2010. Inflammatory cytokine-induced intercellular adhesion molecule-1 and vascular cell adhesion molecule- 1 in mesenchymal stem cells are critical for immunosuppression. Journal of Immunology 184(5): 2321-2328.

Ren, G., Zhang, L., Zhao, X., Xu, G., Zhang, Y., Roberts, A.I., Zhao, R.C. \& Shi, Y. 2008. Mesenchymal stem cellmediated immunosuppression occurs via concerted action of chemokines and nitric oxide. Cell Stem Cell 2(2): 141-150.

Rheinländer, A., Schraven, B. \& Bommhardt, U. 2018. CD45 in human physiology and clinical medicine. Immunology Letters 196: 22-32.

Scheers, I., Lombard, C., Paganelli, M., Campard, D., Najimi, M., Gala, J.L., Decottignies, A. \& Sokal, E. 2013. Human umbilical cord matrix stem cells maintain multilineage differentiation abilities and do not transform during longterm culture. PLoS ONE 8(8): e71374.

Selmani, Z., Naji, A., Zidi, I., Favier, B., Gaiffe, E., Obert, L., Borg, C., Saas, P., Tiberghien, P., Rouas-Freiss, N., Carosella, E.D. \& Deschaseaux, F. 2008. Human leukocyte antigen-G5 secretion by human mesenchymal stem cells is required to suppress $\mathrm{T}$ lymphocyte and natural killer function and to induce CD4+CD25highFOXP3+ regulatory T cells. Stem Cells 26(1): 212-222.

Shaer, A., Azarpira, N., Aghdaie, M.H. \& Esfandiari, E. 2014. Isolation and characterization of human mesenchymal stromal cells derived from placental decidua basalis; Umbilical cord Wharton's jelly and amniotic membrane. Pakistan Journal of Medical Sciences 30(5): 1022-1026.

Tse, W.T., Pendleton, J.D., Beyer, W.M., Egalka, M.C. \& Guinan, E.C. 2003. Suppression of allogeneic T-cell proliferation by human marrow stromal cells: Implications in transplantation. Transplantation 75(3): 389-397.

Ude, C.C., Ng, M.H., Chen, C.H., Htwe, O., Amaramalar, N.S., Hassan, S., Djordjevic, I., Rani, R.A., Ahmad, J., Yahya, N.M., Saim, A.B. \& Idrus, R.B. 2015. Improved functional assessment of osteoarthritic knee joint after chondrogenically induced cell treatment. Osteoarthritis and Cartilage 23(8): 1294-1306.

Vellasamy, S., Sandrasaigaran, P., Vidyadaran, S., George, E. \& Ramasamy, R. 2012. Isolation and characterisation of mesenchymal stem cells derived from human placenta tissue. World Journal of Stem Cells 4(6): 53-61.

Wagner, W., Wein, F., Seckinger, A., Frankhauser, M., Wirkner, U., Krause, U., Blake, J., Schwager, C., Eckstein, V., Ansorge, W. \& Ho, A.D. 2005. Comparative characteristics of mesenchymal stem cells from human bone marrow, adipose tissue, and umbilical cord blood. Experimental Hematology 33(11): 1402-1416.
Wang, H.S., Hung, S.C., Peng, S.T., Huang, C.C., Wei, H.M., Guo, Y.J., Fu, Y.S., Lai, M.C. \& Chen, C.C. 2004. Mesenchymal stem cells in the Wharton's jelly of the human umbilical cord. Stem Cells 22(7): 1330-1337.

Wang, M., Qiu, Y., Wang, X., Zhao, F., Jin, M., Xu, M., Rong, R., Ge, H., Zhang, Y., Wang, X. \& Zhu, T. 2011. Role of HLA-G and NCR in protection of umbilical cord blood haematopoietic stem cells from NK cell mediated cytotoxicity. Journal of Cellular and Molecular Medicine 15(10): 2040-2045

Wang, M., Yuan, Q. \& Xie, L. 2018. Mesenchymal stem cell-based immunomodulation: Properties and clinical application. Stem Cells International 2018: 3057624.

Weiss, A.B.R. \& Dahlke, M.H. 2019. Immunomodulation by Mesenchymal Stem Cells (MSCs): Mechanisms of action of living, apoptotic, and dead MSCs. Frontiers in Immunology 10: 1191

Weiss, M.L., Anderson, C., Medicetty, S., Seshareddy, K.B., Weiss, R.J., Vander Werf, I., Troyer, D. \& McIntosh, K.R. 2008. Immune properties of human umbilical cord Wharton's jelly-derived cells. Stem Cells 26(11): 28652874 .

Ylöstalo, J.H., Bartosh, T.J., Coble, K. \& Prockop, D.J. 2012. Human mesenchymal stem/stromal cells cultured as spheroids are self-activated to produce prostaglandin E2 that directs stimulated macrophages into an anti-inflammatory phenotype. Stem Cells 30(10): 2283-2296.

Jezamine Lim, Sue Ping Eng, Yeoh Wei Yen, Low Yik Wan, Nur Mohd Shafwan Bin Jusoh, Ain Syahirah Binti Rahmat, Amirah Shahrani, Faiq Bahrani Yahya, Rushda Adiba Abdul Rahman, Shinsmon Jose \& Min Hwei $\mathrm{Ng}^{*}$

Centre for Tissue Engineering \& Regenerative Medicine

Universiti Kebangsaan Malaysia Medical Centre

Jalan Yaacob Latif

56000 Kuala Lumpur, Federal Territory

Malaysia

Zainul Rashid Mohamad Razi

Department of Obstetrics and Gynaecology

Universiti Kebangsaan Malaysia Medical Centre

Jalan Yaacob Latif

56000 Kuala Lumpur, Federal Territory

Malaysia

Leong Chooi Fun

Department of Haematology

Universiti Kebangsaan Malaysia Medical Centre

Jalan Yaacob Latif

56000 Kuala Lumpur, Federal Territory

Malaysia

*Corresponding author; email: angela@ppukm.ukm.edu.my

Received: 25 February 2020

Accepted: 9 October 2020 